\title{
Archaeobotanical Approaches in the Study of Food Production in Remote Oceania
}

\author{
Maureece J. Levin ${ }^{1 *}$ \\ ${ }^{1}$ Archaeology Center, Stanford University, Stanford, California, USA. \\ *mjlevin@stanford.edu
}

\begin{abstract}
This short topical review discusses recent archaeobotanical approaches to understanding food production in Remote Oceania (eastern Melanesia, Micronesia, and Polynesia). The region presents some preservation and interpretative challenges, both due to the lack of cereal crops and the hot and humid climate that prevails through much of the area. Nevertheless, archaeobotanical analyses provide insight into topics such the transport of crops between islands and anthropogenic environmental change.
\end{abstract}

Received January 27, 2017

OPEN ӘACCESS

Accepted July 11, 2017

DOI 10.14237/ebl.8.1.2017.882

Keywords Archaeobotany, Archaeology, Pacific Islands, Agriculture, Food production, Remote Oceania

Copyright (c) 2017 by the author(s); licensee Society of Ethnobiology. This is an open-access article distributed under the terms of the Creative Commons Attribution-NonCommercial 4.0 International Public License (https://creativecommons.org/licenses/by-nc/4.0), which permits non-commercial use, distribution, and reproduction in any medium, provided the original author and source are credited.

\section{Introduction}

Food production is a major topic of archaeological and anthropological research in the region known as the Remote Pacific (eastern Melanesia, Micronesia, and Polynesia). This region encompasses a diversity of agricultural systems adapted to volcanic (high) islands and coral atolls. Most food production here relies heavily on crops and animals that people transported with them when they originally settled these islands (Kirch 2000). These imported products are largely drawn from an agricultural system that people living in the Malayo-Oceanic tropics had independently developed by $6950 \mathrm{cal} \mathrm{BP}$ (Denham et al. 2003).

Although the amount of archaeobotanical publication in Remote Oceania and even the Pacific in general is less than in locations such as Southwest Asia, China, or Mesoamerica, interest in the relationship between people and plants in the region's past has been of interest to researchers for decades. Especially notable is botanist Douglas Yen's work in the mid and late $20^{\text {th }}$ century. In Remote Oceania, his extensive work includes the study of the early use of sweet potato (Ipomoea batatas) in the Pacific (e.g., Rosendahl and Yen 1971; Yen 1974, 1990) and human-environment relationships on the Polynesian outlier of Tikopia (Kirch and Yen 1982). Further- more, there has been a florescence of research in the field over the past 25 years since Hather's (1992) review of the topic. This short review introduces some recent research and explores issues specific to conducting archaeobotanical research in Remote Oceania.

\section{Geographical Setting}

At a basic level, Remote Oceania is the region of the Pacific Islands that was settled by Austronesianspeaking peoples, beginning some three to four millennia ago, and their descendants. Initial settlement of the region is associated primarily with Lapita pottery producers (Denham et al. 2012; Sheppard 2011), although western Micronesia (e.g., The Mariana Islands and Palau) was settled separately by other Austronesian speakers (Carson and Switzerland 2013; Clark et al. 2006). The initial settlers of Remote Oceania all relied, to some extent, on imported domesticated plants of the Malayo-Oceanic tropics, which played a major role in the success of colonization (Kirch 2000). In this sense, the archaeobotany of the region is foundational to understanding both human migrations and human-environment dynamics.

\section{Analytical Techniques}

While in much of the world, agricultural systems rely on domesticated cereals, Remote Oceania is a major 
region where cereals were not a staple in dietary prehistory. Instead, most of the domesticated staples are roots, tubers, or tree fruits. Charred plant macroremains can be recovered successfully through flotation, although charred remains other than wood charcoal are less common in Remote Oceania than in most temperate regions. Additionally, root and tuber macroremains (and, in most cases, tree fruits and nuts), cannot be quantified in the same way as cereals. However, they are present at some sites and can be useful in the study of subsistence. This is true of both tree crops (e.g., Kahn and Ragone 2013) and roots and tubers (e.g., Ladefoged et al. 2005; Ussher 2015). Compounding this is the generally poor preservation of organic materials in the environments of the tropical Remote Pacific, which are largely (though not exclusively) warm and humid, often with acidic volcanic or alkaline coral sediments.

For this reason, anthracological (wood charcoal) research has been a focus in Remote Oceania. For example, in New Caledonia, Dotte-Sarout (2017; Dotte-Sarout et al. 2013) has demonstrated the presence of highly domesticated forests in the second millennium cal A.D.. In the Marquesas Islands, Huebert has documented activities such as rapid changes in forest composition due to human habitation (Huebert and Allen 2016) and fuel use in earth ovens (Huebert et al. 2010). Murakami has long worked in anthracology throughout Remote Oceania, studying activities such as the development of agroforestry on Kosrae, Micronesia (Athens et al. 1996), and the introduction of breadfruit (Artocarpus altilis) to Hawai'i in the $13^{\text {th }}$ century A.D. (McCoy et al. 2010). In the temperate zone of Remote Oceania (New Zealand and environs), Maxwell has recently studied Moriori managed forests on the Chatham Islands (e.g., Maxwell et al. 2016).

Additionally, archaeobotanical work in Remote Oceania increasingly emphasizes plant microremain analysis. Since the latter half of the $20^{\text {th }}$ century, archaeologists working in this region have regularly used pollen from cores as complementary paleoenvironmental data. However, because wind-blown pollen grains are the most numerous and they provide a regional rather than strictly local signature, pollen is generally less useful than macroremains in direct dietary interpretation (but see also Horrocks et al. 2003 for an example of the use of pollen from coprolites for dietary studies). Phytoliths (silica bodies present in the structural part of many plants) and starch grains provide a more localized signature appropriate for questions about inter- and intra-site variability, crop processing, and specific agricultural practices.

Using multiple types of plant microremains, Horrocks has published on plant introductions and use throughout the Pacific region, including Fiji (Horrocks 2007), Hawai'i (Horrocks and Rechtman 2009), and the Mariana Islands (Horrocks et al. 2015), among other places. Allen and Ussher (2013), working on the Marquesas Islands, used starch to document the exploitation of several introduced plant species and to better understand tool use. Research from Tromp and Dudgeon (2015) on dental calculus from Rapa Nui (Easter Island) also shows the importance of sweet potato to human diet in East Polynesia prior to European contact. Moreover, it highlights how taphonomic pathways are a crucial consideration in microremain analysis. As the inclusion of microbotanical analyses in Remote Oceanic food production research continues to become more standard, we can expect to see modifications of and improvements in our understanding of human movement and subsistence strategies within the region.

\section{Multi-Proxy Investigation}

The use of multi-proxy methods to answer larger questions about food production in Remote Oceania is essential, especially because of the poor preservation in the humid tropics and the largely arboricultural economy. Many archaeobotanical studies in the region use multiple types of plant remains to study past food production (e.g., Horrocks et al. 2003, 2015; Horrocks and Rechtman 2009; Levin 2016; Tromp and Dudgeon 2015; Ussher 2015). As every class of archaeobotanical remains has its own limitations, a multi-proxy approach provides a more complete picture of food production in the past.

Larger projects, such as the Hawai'i Biocomplexity Project (Kirch et al. 2004; Vitousek et al. 2004) have developed broad, interdisciplinary agendas, incorporating archaeobotanical data with other lines of evidence such as soil chemistry and landscape archaeology. The Hawai'i Biocomplexity Project specifically investigated the prehistory of landscape use and sociopolitical systems on the Hawaiian Islands, much of which involved the study of terraced fields. These types of data are key to understanding the origins and spread of Pacific subsistence strategies that enabled the settlement of Remote Oceania. While multi-proxy strategies are certainly not new or 
uncommon in many regions, a similar approach applied more broadly may yield new insights into the exploitation of roots, tubers, and trees, as well as human landscape management, even where other archaeobotanical data (such as charred seeds) are abundant.

\section{Conclusion}

In conclusion, archaeobotany, while previously underutilized in Remote Oceania, has been growing at a rapid pace since the late $20^{\text {th }}$ century. Preservation can sometimes be an issue, due to the largely humid, tropical environment and coastal sites submerged by fluctuating sea levels. Nevertheless, archaeobotanical data are yielding new information about the food production systems that Pacific Islanders introduced to new environments and the ways that human-plant relationships have enabled settlement and survival. Ultimately, the field is moving towards a more integrated, multi-proxy approach, which will continue to remain important to answering the most pressing archaeobotanical questions in the region.

\section{Acknowledgments}

This paper was greatly improved by comments from Jaime Kennedy, Chantel Saban, and Katherine Seikel, as well the editor, John M. Marston, and two anonymous reviewers. Any shortcomings or errors are my own.

\section{Declarations}

Permissions: None declared.

Sources of Funding: None declared.

Conflicts of Interest: None declared.

\section{References Cited}

Allen, M.S., and E. Ussher. 2013. Starch Analysis

Reveals Prehistoric Plant Translocations and Shell Tool Use, Marquesas Islands, Polynesia. Journal of Archaeological Science 40:2799-2812. DOI:10.1016/ j.jas.2013.02.011.

Athens. J.S., J.V. Ward, and G.M. Murakami. 1996. Development of an Agroforest on a Micronesian High Island: Prehistoric Kosraean Agriculture. Antiquity 70:834-846. DOI:10.1017/ S0003598X00084106.

Carson, M. and C. Switzerland. 2013. First Settlement of Remote Oceania: Earliest Sites in the Mariana Islands. Springer, New York.
Clark, G., A. Anderson, and D. Wright. 2006. Human Colonization of the Palau Islands, Western Micronesia. Journal of Island and Coastal Archaeology 1:215-232. DOI:10.1080/15564890600831705.

Denham, T.P., C. Bronk Ramsey and J. Specht. 2012. Dating the Appearance of Lapita Pottery in the Bismarck Archipelago and its Dispersal to Remote Oceania. Archaeology in Oceania 47:39-46. DOI:10.1002/j.1834-4453.2012.tb00113.x.

Denham, T.P., S.G. Haberle, C. Lentfer, R. Fullagar, J. Field, M. Therin, N. Porch, and B. Winsborough. 2003. Origins of Agriculture at Kuk Swamp in the Highlands of New Guinea. Science 301:189-193. DOI:10.1126/science.1085255.

Dotte-Sarout, E. 2017. Evidence of Forest Management and Arboriculture from Wood Charcoal Data: An Anthracological Case Study from Two New Caledonia Kanak Pre-Colonial sites. Vegetation History and Archaeobotany 26:195-211. DOI:10.1007/s00334-16-0580-0.

Dotte-Sarout, E., J. Ouetcho, J. Bolé, D. Barret, and C. Sand. 2013. Of Charcoals and Forests: Results and Perspectives from an Archaeobotanical Investigation of Precolonial Kanak Settlement Sites in New Caledonia. In Pacific Archaeology: Documenting the Past 50,000 Years, edited by G.R. Summerhayes and H. Buckley, pp. 120-137. Department of Anthropology \& Archaeology, University of Otago, New Zealand.

Hather, J.G. 1992. The Archaeobotany of Subsistence in the Pacific. World Archaeology 24:70-81. DOI:10.1080/00438243.1992/9980194.

Horrocks, M. 2007. Evidence for Introduced Taro (Colocasia esculenta) and Lesser Yam (Dioscorea esculenta) in Lapita Era (c. 3050-2500 cal. BP) Deposits from Bourewa, Southwest Vitu Levu Island, Fiji. Journal of Archaeological Science 34:739_ 748. DOI:10.1016/j.jas.2006.07.011.

Horrocks, M., G.J. Irwin, M.S. McGlone, S.L. Nichol, and L.J. Williams. 2003. Pollen, Phytoliths and Diatoms in Prehistoric Coprolites from Kohika, Bay of Plenty, New Zealand. Journal of Archaeological Science 30:13-30. DOI:10.1006/jasc.2001.0714.

Horrocks, M., J. Peterson, and M.T. Carson. 2015. Pollen, Starch, and Biosilicate Analysis of Archaeological Deposits on Guam and Saipan, Mariana Islands, Northwest Pacific: Evidence for Chamor- 
ro Subsistence Crops and Marine Resources. The Journal of Island and Coastal Archaeology 10:97-110. DOI:10.1080/15564894.2014.921960.

Horrocks, M. and R.B. Rechtman. 2009. Sweet Potato (Ipomoea batatas) and Banana (Musa sp.) Microfossils in Deposits from the Kona Field System, Islands of Hawaii. Journal of Archaeological Science. 36:1115-1126. DOI:10.1016/j.jas.2008.12.014.

Huebert, J.M. and M.S. Allen. 2016. Six Centuries of Anthropogenic Forest Change on a Polynesian High Island: Archaeological Charcoal Records from the Marquesas Islands. Quaternary Science Reviews 137:79-96. DOI:10.1016/ j.quascirev.2016.01.017.

Huebert, J.M., M.S. Allen, and R.T. Wallace. 2010. Polynesian Earth Ovens and Their Fuels: Wood Charcoal Remains from Anaho Valley, Nuku Hia, Marquesas Islands. The Journal of the Polynesian Society 119:61-97. DOI:10.2307/20707516.

Kahn, J.G., and D. Ragone. 2013. Identification of Carbonized Breadfruit (Artocarpus altilis) Skin: Refining Site Function and Site Specialization in the Society Islands, East Polynesia. Journal of Ethnobiology 33:237-258. DOI:10.2993/0278-077133.2.237.

Kirch, P.V. 2000. On the Road of the Winds: An Archaeological History of the Pacific Islands Before European Contact. University of California Press, Berkeley, CA.

Kirch, P.V., A.S Hartshorn, O.A. Chadwick, P.M. Vitousek, D.R. Sherrod, J. Coil, L. Holm, and W.D. Sharp. 2004. Environment, Agriculture, and Settlement Patterns in a Marginal Polynesian Landscape. Proceedings of the National Academy of Sciences 101:9936-9941. DOI:10.1073/ pnas.0403470101.

Kirch, P.V. and D.E. Yen. 1982. Tikopia: The Prehistory and Ecology of a Polynesian Outlier. Bishop Museum Press, Honolulu, HI.

Ladefoged, T.N., M.W. Graves, and J.H. Coil. 2005. The Introduction of Sweet Potato in Polynesia: Early Remains in Hawai'i. The Journal of the Polynesian Society 114:359-373.

Levin, M.J. 2016. Roasting Breadfruit in the Pacific: A Combined Plant Macroremain and Phytolith
Analysis from Pohnpei, Federated States of Micronesia. Archaeology in Oceania 51:70-76. DOI:10.1002/arco.5081.

Maxwell, J.J., J.D. Howarth, M.J. Vandergoes, G.E. Jacobsen, and I.G. Barber. 2016. The Timing and Importance of Arboriculture and Agroforestry in a Temperate East Polynesia Society, the Moriori, Rekohu (Chatham Island). Quaternary Science Reviews 149:306-325. DOI:10.1016/ j.quascirev.2016.08.006.

McCoy, M.D., M.W. Graves, and G. Murakami. 2010. Introduction of Breadfruit (Artocarpus altilis) to the Hawaiian Islands. Economic Botany 64:374-381. DOI: $10.1007 / \mathrm{s} 12231-010-9140-1$.

Rosendahl, P., and D.E. Yen. 1971. Fossil Sweet Potato Remains from Hawaii. The Journal of the Polynesian Society 80:378-385.

Sheppard, P.J. 2011. Lapita Colonization Across the Near/Remote Oceania Boundary. Current Anthropology 52:799-840. DOI:10.1086/662201.

Tromp, M., and J.V. Dudgeon. 2015. Differentiating Dietary and Non-Dietary Microfossils Extracted from Human Dental Calculus: The Importance of Sweet Potato to Ancient Diet on Rapa Nui. Journal of Archaeological Science 54:54-63. DOI:10.1016/ j.jas.2014.11.024.

Ussher, E. 2015. Agriculture in Tongan Prehistory: An Archaeobotanical Perspective. Unpublished Doctoral Dissertation, Department of Archaeology and Natural History, College of Asia Pacific, The Australian National University, Canberra, Australia.

Vitousek, P.M., T.N. Ladefoged, P.V. Kirch, A.S. Hartshorn, M.W. Graves, S.C. Hotchkiss, S. Tuljapurkar, and O.A. Chadwick. 2004. Soils, Agriculture, and Society in Precontact Hawai'i. Science 304:1665-1669. DOI:10.1126/ science.1099619.

Yen, D.E. 1974. The Sweet Potato and Oceania: An Essay in Ethnobotany. Bishop Museum Press, Honolulu, HI.

Yen, D.E. 1990. The Sweet Potato in the Pacific: The Propagation of the Plant in Relation to its Distribution. The Journal of the Polynesian Society 69:368375. 